\title{
O PARADIGMA DO DESENVOLVIMENTO: do mito fundador ao novo desenvolvimento
}

\begin{abstract}
Anete B.L. Ivo*
Este artigo busca historicizar contextos que reorientaram a noção de desenvolvimento, no Brasil, desde os anos 30-80, passando pelo ajuste neoliberal dos anos 90, até inflexões atuais que indagam se o novo intervencionismo massivo e estratégico do Estado em políticas sociais para os mais pobres aponta para um novo modelo de desenvolvimento. A análise apresenta inflexões do modelo cepalino de 50-60 e tenta priorizar dimensões sociais na mediação das contradições entre a economia, a política e o institucional. $\mathrm{O}$ fio condutor toma dois vetores analíticos: o tema do conflito (redistributivo) e o da integração. O primeiro é assentado nas coalizões das classes e confronto entre atores nacionais e agências multilaterais; e o da integração, na contraface do conflito, considera a abertura das políticas públicas e, também, a inovação de atores sociais e políticos em novos arranjos voltados para os objetivos do bem-estar social e da cidadania, de uma perspectiva mais sustentada.

PALAVRAS-CHAVE: desenvolvimento, modernização, ajuste estrutural, Estado, políticas sociais, pobreza.
\end{abstract}

A noção de desenvolvimento aparece no horizonte da economia e da política e no campo das práticas dos atores políticos e institucionais no Pós-Segunda Guerra. Constitui-se num "mito fundador", no sentido antropológico do termo, pelo qual a narrativa e os sentidos associados a essa ideia representam "uma solução imaginária das tensões, conflitos e contradições" (Chaui, 2000) enfrentadas pela sociedade brasileira, em relação aos dilemas e desafios da modernização econômica, política e institucional. Para Chauí, referindose à nação, “[...] este mito impõe um vínculo interno com o passado como origem, isto é com um passado que não cessa nunca.” (p.9). Da perspectiva do desenvolvimento, abrange um repertório de problemas de interpretação da nação brasileira e se projeta no futuro, como "solução possível", mas também deliberada, no sentido de ser promovida pelo Estado, com vistas a superar os óbices da tradição e implementar um projeto de moder-

* Doutora em Sociologia. Professora do Programa de PósGraduação em Ciências Sociais da UFBA e pesquisadora do Centro de Recursos Humanos/UFBA.

Estrada de São Lázaro, 197. Federação. Cep: 40210-730. Salvador-Bahia-Brasil. anetivo@hotmail.com. nização nacional urbano-industrial para o país. Esse "mito" atualiza o ideário iluminista ${ }^{1}$ do "progresso" adaptado à singularidade da formação da sociedade brasileira, que articula, de forma complexa e contraditória, o regime de acumulação às condições de reprodução das classes, e os processos de dominação que mobilizam grupos e poder político, e, ao mesmo tempo, forças externas do regime de acumulação. A problemática clássica da sociológica do desenvolvimento, entendida por Cardoso e Faletto (1970), na crítica ao modelo estruturalista de desenvolvimento cepalino, envolvia o estudo das "estruturas de dominação e das formas de estratificação social que condicionam os mecanismos e tipos de controle e decisão do sistema econômico em cada caso particular.” (p.37).

Os debates atuais discutem as possibilidades e contornos da emergência de um "neodesenvolvimentismo” (Boschi; Gaitán, 2008; Bresser

${ }^{1}$ Aqui entendido não como a era da Razão, que acompanhou o pensamento de filósofos até o século XVIII, em países da Europa, mas pela ênfase nos valores do progresso e na tese do aperfeicoamento do homem com base num conhecimento racional e científico, capaz de superar o poder e as ideologias tradicionais a serviço da melhoria da sociedade. 
Pereira, 2004, 2006) na agenda pública de países da América Latina e no Brasil, pelo novo intervencionismo do Estado. Diante da crise estrutural do capitalismo contemporâneo e os resultados apresentados pelas economias de países latino-americanas - que combinam crescimento com distribuição, com base num papel ativo e central do Estado -, pretendo trazer, neste artigo, uma contribuição de natureza mais sociológica, afinada com a historicidade de processos de longo prazo, em vista de retraçar um fio condutor de inflexões e rupturas do pacto prevalecente entre Estado, burguesia e trabalhadores assalariados (que sustentou o projeto nacional-desenvolvimentista dos anos trinta aos setenta). Tais inflexões possibilitam observar novos arranjos, atores e dimensões entre Estado, mercado e sociedade, no encaminhamento da questão social, no contexto pós-consenso de Washington. Esse resgate ultrapassa abordagens exclusivamente econômicas (objetivos da estabilidade e da capacidade competitiva do país), ou restritas ao papel intervencionista do Estado brasileiro, de uma perspectiva exclusivamente institucional, privilegiando dimensões sociais nas temáticas do conflito e no seu contraponto, ou seja, a temática da integração social, que envolve, de um lado, a justiça redistributiva e, de outro, o horizonte da política voltada para o objetivo de bemestar social e da cidadania, sustentadas por coali- "neodesenvolvimentismo" hoje, ultrapassando perspectivas que entendam o desenvolvimento orientado para a competitividade, estabilidade e crescimento, ou de retomada do protagonismo do Estado nacional. A segunda parte sintetiza as teses do desenvolvimento dos anos cinquenta até o início dos anos setenta. Abrange tanto a formulação do ISEB como a crítica ao paradigma do desenvolvimento periférico, com base na coalizão das classes, formulado pela escola paulista [F.H.Cardoso; E. Faletto (1970), F. Oliveira [1972] 1976]. Na sequência, o artigo apresenta as inflexões dos anos oitenta, marcadas, no âmbito internacional, por um diagnóstico conservador da governabilidade, que fundamentou a ruptura do pacto distributivo do Estado de Bem-estar pela tese do déficit fiscal. Tal diagnóstico conflitou, internamente, com o processo de redemocratização das instituições jurídicas e políticas do país, orientado por diversos e novos atores sociais em luta por direitos da cidadania, como um novo projeto de Estado, mais próximo de um regime de bem-estar assentado numa concepção de universalidade do direito social. A esse diagnóstico conservador das agências multilaterais seguem-se, nos anos noventa, mudanças do ajuste estrutural do Estado, voltadas para a estabilidade e em favor de uma desconcentração do Estado nacional pela via da descentralização das políticas e dos objetivos do desenvolvimento endógeno, local e sustentável. A quarta parte discute o tema da "integração social", orientado pela agenda do pós-consenso de Washington e por organizações multilaterais, restrito a um consenso ampliado de combate à pobreza $\mathrm{e}$ dissociado da dimensão estruturante do mercado de trabalho (Ivo, 2001). A conclusão do artigo indaga se a intervenção estratégica do Estado em políticas sociais massivas pró-pobres, como via de enfrentamento das desigualdades estruturais, sociais e territoriais, aponta para um novo modelo de desenvolvimento de caráter mais redistributivo e voltado para objetivos de bem-estar. Ou seja, destaca o debate atual do novo desenvolvimento na implantação de políticas sociais focadas "sobre os mais pobres", como políticas de integração social, as quais estariam condicionando padrões de um crescimento sustentado pelo mercado interno, 
segundo as novas teses das agências oficiais e multilaterais. Até que ponto esses fatores distinguem um novo papel do Brasil na nova ordem mundial?

\section{O LEGADO: antecedentes da noção do desen- volvimento, entre tradição e modernidade ${ }^{2}$}

Diferentes interpretações da sociedade brasileira antecederam o debate sobre o papel estratégico do Estado nacional, orientado pelo pensamento "desenvolvimentista" da década de 50-60. A tradição das ciências sociais buscava entender os fundamentos da sociedade brasileira, a relação entre a tradição e a modernidade, que impedia o projeto racional civilizador, no sentido de assimilação de atributos de uma sociedade com traço fortemente iluminista, assentada no triunfalismo da Razão e influenciada pelo "desejo do outro" europeu.

Nessa linha, o retorno a algumas das teses de Gilberto Freire, em Casa Grande \& Senzala [1933] e de Sérgio Buarque de Holanda, em Raízes do Brasil [1936] ajuda a recompor algumas linhas desse dilema. ${ }^{3}$ Freire analisa as origens do patriarcalismo da família brasileira, base de organização e dominação da estrutura fundiária e escravocrata colonial, centrado no domínio do patriarca sobre parentes, filhos, esposa, escravos etc., destacando a integração de tais elementos, mesmo em condições de subalternidade, e apontando para a singularidade do processo de miscigenação entre brancos, negros e indígenas, no Brasil.

Em Raízes do Brasil [1936], Holanda discute traços da cultura política brasileira, sintetizados na representação do "homem cordial". Para ele, a sociedade brasileira, influenciada pela tradição ibérica - patrimonial e autoritária, mas mediada por

${ }^{2}$ Aqui distingo as noções de modernidade e modernização. A primeira entendida da perspectiva de pensar o tempo presente à luz de uma ruptura com o passado. A segunda, a modernização, como um processo racionalizador impulsionado pelo Estado, em vista do progresso técnico e do crescimento econômico. Ambas as noções influenciam a mudança e a transformação da sociedade brasileira na implantação de uma sociedade urbano-industrial capitalista.

${ }^{3}$ Este resgate tem função indicativa, apenas para apontar dilemas enfrentados no debate clássico, com a consciência dos limites e riscos implícitos aos esforços de síntese. relações primárias de proteção, sem o filtro da racionalidade moderna -, era incompatível com o funcionamento da burocracia e das regras democráticas do Estado moderno. Robert Wegne (2009) considera que Sérgio Buarque de Holanda não enxerga possibilidades de que "a cordialidade se transformasse em civilidade. [...] que exige algum tipo de racionalidade e abstração.” (p.218).

Na linha de discussão sobre os óbices à modernização brasileira, incluem-se, também, interpretações e estudos relativos à herança das relações escravistas, patrimoniais e agrárias, próprias ao sistema colonial, que seriam impeditivas da plena adoção de atributos racionais da sociedade capitalista. A interseção entre raça e classe, no Brasil, foi objeto de pesquisas da escola paulista sobre relações raciais, liderada por Florestan Fernandes e alguns dos seus discípulos: Fernando Henrique Cardoso, Otávio Ianni, Maria Sylvia de Carvalho Franco, entre outros. ${ }^{4}$

Do ponto de vista sociológico, as preocupações e os diagnósticos sobre a tradição traziam implícita a perspectiva de "mudança provocada", expressão usada pelos sociólogos dos anos 50, o que, segundo Villas Boas (2006), "traduzia o desejo de intervir [...] para mudar a feição das instituições, das mentalidades, da distribuição de poder, impondo a regularidade nova à conduta cotidiana de homens e mulheres" (p.13). Tal racionalização pode ser observada no livro de Florestan Fernandes Mudança social no Brasil (1960), que mostra a participação ativa de Florestan em prol da educação universal e pública, ao final dos anos 1950, da campanha em defesa da escola primária, quando da discussão da Lei de Diretrizes e Bases da Educação (Arruda, 2009, p.316). Para Arruda (p.316), Florestan Fernandes entendia que "o sistema educacional brasileiro não respondia aos imperativos de uma sociedade em processo de modernização, representando um obstáculo às mudanças em curso, caracterizando o fenômeno de "demora cultural” (p.317). Do mesmo modo, ao criticar a

${ }^{4}$ Thales de Azevedo introduziu esse debate em Les élites de couleur dans une ville brésilienne originalmente publicada pela Unesco [1953]. 
heteronomia presente na “situação de castas”, que impedia o negro de assimilar suas condições de "classe", Fernandes destacava os processos de "desajuste estrutural" e o "isolamento sociocultural" dos traços da tradição e da discriminação em relação às conquistas civilizadas.

Resulta deste processo o "desajustamento estrutural”, a "desorganização social” típicas dos descendentes dos africanos, relegados a viver um estado de marginalidade social, verdadeiros proscritos das conquistas civilizadas. O preconceito e outras expressões de discriminação exerceram a função "de manter a distância social" e de reproduzir o "isolamento sociocultural", tendo em vista a preservação das "estruturas sociais arcaicas”. (Arruda, 2009, p.317-318).

Diferentemente dessas interpretações, que discutem as relações socioculturais e políticas da modernidade brasileira, Caio Prado Junior [1933] constrói uma interpretação histórica singular da sociedade brasileira, orientada pela categoria marxiana de “formação social”. Enfatiza a relação entre a colônia e a nação, ou a passagem entre a condição de colônia para a formação da nação, e reconhece, nessa relação, impasses para a transição ${ }^{5}$ modernizadora.

Com base numa abordagem econômica da ordem colonial brasileira, Caio Prado Júnior analisa o "sentido do projeto colonial" que orienta a formação da colônia na direção de uma construção da nação. Para ele, a formação brasileira só pode ser entendida pelo "sentido da colonização" voltado para fora, cujo objetivo era fornecer produtos para o mercado externo e atender aos interesses da coroa portuguesa. Esse "sentido colonial” formava a totalidade entre as partes constitutivas da economia e da política colonial brasileiras, articuladas à metrópole. Prado Junior reconhecia também uma desarticulação entre a produção voltada para fora, que ele chama de setor orgânico da sociedade colonial agroexportadora, e o setor inorgânico, constituído pela maior parte da população voltada

\footnotetext{
O uso da categoria marxiana "formação social” busca apreender a complexidade das sociedades históricas onde sobrevivem diferentes modos de produção que, articulados, produzem uma totalidade histórica complexa e
} contraditória. para o consumo interno e que, de acordo com o autor, tem papel subalterno. Para ele é a esse "setor inorgânico" e subalterno e a essa grande maioria "desqualificada" que a nação brasileira "deve seguir" no futuro, conforme analisa Ricúpero (2009, p.235). Talvez esteja em Caio Prado Junior a síntese das principais contradições da sociedade brasileira, entre as instituições políticas coloniais e a estrutura socioeconômica do país. Tais contradições vão fundamentar os dilemas futuros do encaminhamento da questão social brasileira, caracterizada pelo enorme contingente de trabalhadores empobrecidos e desprotegidos de direitos sociais do mercado informal e por uma sociedade profundamente desigual no acesso aos direitos. $\mathrm{Na}$ sua análise, Caio Prado destaca "um desacordo fundamental entre o sistema econômico legado pela colônia e as novas necessidades de uma nação livre e politicamente emancipada”. Suas interpretações suscitaram debates nos círculos da esquerda brasileira, exatamente porque confrontavam com a tese, então predominante, de que a revolução econômica e nacional brasileira implicava a superação dos considerados traços “feudais”, como etapa necessária, e viam, na burguesia nacional, o ator central do projeto de desenvolvimento nacional. ${ }^{6}$

Caio Prado Junior, no seu livro A Revolução Brasileira [1966], considera equivocada a transposição de um processo de transição de épocas passadas, ocorrido em outras sociedades europeias, do feudalismo para o capitalismo, para países como o Brasil. Para ele, a burguesia nacional não existia e nem poderia ser um ator central do projeto de desenvolvimento e modernização nacional, porque estava bloqueada internamente pelas estruturas de dominação tradicionais, e, externamente, pela dependência do capital internacional. Com essas teses, Caio Prado Junior deixa um lastro histórico sobre os vínculos da dependência dos processos de acumulação no país que, certamente, constituíram-se em referenciais importantes para a crítica

\footnotetext{
${ }^{6}$ Parte da esquerda brasileira, sob a liderança do Partido Comunista Brasileiro (PCB), acreditava que as classes empresariais, aliadas aos trabalhadores, poderiam adotar posições nacionalistas e produzir, ao mesmo tempo, uma revolução burguesa e nacional.
} 
da escola paulista às teses do desenvolvimento propostas pelo ISEB. ${ }^{7}$

As interpretações desses autores (e outras que aqui não foram tratadas) revelam que uma das principais contradições do país estava entre o sistema produtivo, voltado para fora, e os óbices para se criar uma organização jurídica e política que adotasse plenamente instituições liberais. Ou seja, os limites da modernização estavam, em grande parte, na "modernidade possível", como formula Faoro (1992). Para ele, entre as duas: "A oposição pode, uma vez que não chega à contradição, e daí, à superação, conciliar-se e acomodar-se num quadro sem afirmação e sem superação" (p.18). Nesse sentido, Faoro expressa a limitação de um projeto de modernização realizado pelo alto e pelas elites e considera que a via central dessa transição passa pela expansão da cidadania.

\section{TESES DO NACIONAL-DESENVOLVIMENTO: do mito fundador do pós-guerra aos anos setenta}

A noção de desenvolvimento adquiriu um lugar hegemônico nas ciências sociais latino-americanas, no período Pós-Segunda Guerra. À luz de um horizonte epistemológico da economia política e associada a um projeto de modernização nacional pela via da industrialização e da urbanização capitalista, a noção é paradigmática de um projeto nacional de "substituição de importações" $\mathrm{com}$

7 O Instituto Superior de Estudos Brasileiros (ISEB), órgão criado em 1955, era dotado de autonomia administrativa, mas vinculado ao Ministério de Educação e Cultura, cuja missão era o ensino e o estudo das ciências sociais. Constituiu-se num núcleo difusor das ideias do desenvolvimentismo e das ações do Estado no governo Juscelino Kubitschek, visando a orientar a burguesia em relação a seu papel nas transformações econômicas, sociais e culturais do país. Participaram desse grupo inúmeros intelectuais brasileiros com formação e orientações distintas, como: Miguel Reale, Sergio Buarque de Holanda, Hélcio Jaguaribe, Roland Corbisier, Guerreiro Ramos, Nelson Werneck Sodré, Antônio Cândido, Candido Mendes, Inácio Rangel, Alvaro Vieira Pinto, Carlos Estevam Martins, Abdiais Nascimento, entre outros. Foi infleunciado pelas ideias da Cepal (Comissão Econômica de Estudos para a América Latina e o Caribe), tendo também como colaboradores Celso Furtado e Heitor Villa Lobos. O ISEB foi extinto após o golpe de 1964. Ver Bresser Pereira (2004) e CPDOC- FGV cpdoc.fgv.br na parte relativa a JK.

${ }^{8} \mathrm{O}$ modelo de substituição de importações refere-se à proposta da CEPAL, aplicada a países como Brasil, México e Argentina e outros, de um planejamento da política eco- base no progresso técnico, e da revolução nacionalista brasileira, a exemplo das teses defendidas pelos intelectuais do Instituto Superior de Estudos Brasileiros (ISEB), na década de cinquenta, da tese sobre a modernização da CEPAL e das críticas posteriores formuladas por intelectuais da escola paulista ${ }^{9}$ a essas teses sobre o subdesenvolvimento.

\section{A noção estratégica de desenvolvimento do ISEB}

Segundo os intelectuais do ISEB, a noção do desenvolvimento referia-se a um regime de acumulação capitalista baseado em industrialização, crescimento econômico e progresso técnico, e modernização das relações produtivas, com base no trabalho assalariado e na elevação do padrão de vida da população, sob a liderança do empresariado nacional. ${ }^{10} \mathrm{~A}$ esse conjunto de mudanças costumou-se chamar de "modernização brasileira". Em termos político-institucionais, a perspectiva nacionaldesenvolvimentista supunha um papel central, deliberado e planejado doEstadonacional, de longo prazo, voltado para dar suporte e impulsionar as transformações da base técnica e econômica, bem como as transformações das instituições políticas e jurídicas.

A articulação entre o econômico e o político sustentava uma coalizão entre a burocracia Estatal, as elites empresariais e os trabalhadores assalariados. O Estado nacional assumiu o papel de ator estratégico do desenvolvimento, visando a gerar as condições institucionais e de infraestrutura para alavancar a economia. Tais condições incluíam as ações protecionistas aos empresários da indústria nacional (o modelo de "substituição das importações”, desde Vargas) e a criação de infraestrutura, de modo a gerar as condições para esses investi-

nômica baseada no processo de industrialização capitalista, voltado para o mercado interno e dependente de políticas protecionistas do Estado à indústria nacional. A adoção dessa política acarretou uma mudança do centro dinâmico da economia brasileira, pelo estímulo às manufaturas. A Cepal considerava que essa política permitiria a acumulação de capitais internos, o que poderia gerar um desenvolvimento autossustentável e duradouro.

${ }^{9}$ Refiro-me à teoria da dependência (Cardoso; Faletto, 1970) e a tese da dualidade da sociedade brasileira (Oliveira, 1972).

${ }^{10}$ Ver Bresser Pereira, 2004 e os textos CPDOC- FGV cpdoc.fgv.br parte relativa à JK de Alzira Abreu. 
mentos, indicados no Plano de Metas (1956-1961) de Juscelino Kubitschek. O Plano contemplou um conjunto integrado de investimentos com metas para o setor público e privado e pouco estímulo ao setor agrário, tendo sido bem sucedido, do ponto de vista do crescimento econômico, à custa de alto endividamento público. Bresser Pereira (2004) assim define a noção estratégica de desenvolvimento formulada pelos intelectuais do ISEB:

É o processo de acumulação de capital; acumulação de progresso técnico e elevação do padrão de vida da população de um país, que se inicia com a revolução capitalista e nacional; é o processo de crescimento sustentado da renda dos habitantes de um país sob a liderança estratégica do Estado nacional e tendo como principais atores os empresários nacionais. O desenvolvimento é nacional porque se realiza nos quadros de cada Estado nacional, sob a égide de instituições definidas e garantidas pelo Estado. (p.57-58).

\section{A teoria da modernização e a noção de marginalidade da Cepal ${ }^{11}$}

O paradigma da modernização, no pós-guerra, converteu-se numa referência central do pensamento latino-americano. Segundo Nun (2001, p.10), para os economistas, essa modernização significava a busca do crescimento sustentado do produto per capita. Para os cientistas políticos, a institucionalização de uma democracia representativa e, para sociólogos, a difusão de valores para a racionalização, o universalismo, o desempenho, a secularização. ${ }^{12} \mathrm{~A}$ tese cepalina apoiava-se no conceito de "subdesenvolvimento" entendido como uma formação histórica singular que opunha um setor "atrasado" a um setor "moderno", uma forma específica de as economias pré-industriais, penetradas pelo capitalismo, passarem para formas mais avançadas. ${ }^{13}$

11 Apresentei essa discussão de forma mais detalhada em Ivo (2008) capítulo IV.

${ }^{12}$ Esse entendimento de Nun, no entanto, não contempla a crítica da economia política e a abordagem sociológica marxiana da dominação de classes, como o fizeram Cardoso e Falleto (1970) e Oliveira (1972).

${ }^{13}$ Ver a crítica central de Francisco de Oliveira (1976, p.9) à perspectiva dualista da CEPAL.
Inerente à tese sobre a singularidade do subdesenvolvimento latino-americano, multiplicaramse argumentos sobre a persistência de uma "cultura da pobreza”, que se constituía em freio para o desenvolvimento. A tese do "círculo vicioso da pobreza" de Nurkse (1963), por exemplo, argumentava que os países subdesenvolvidos tinham uma renda per capita muito baixa e voltada totalmente para o autoconsumo, o que impossibilitava a capacidade de inversão, fazendo com que a pobreza se perpetuasse. ${ }^{14}$ Considerava que a via para romper tal "ciclo vicioso" seria a atração de investimentos estrangeiros, empréstimos no exterior e assistência técnica de organismos internacionais. A hipótese era a de que, uma vez estabelecido o polo moderno, seus efeitos positivos se expandiriam, e a produção, o consumo e os valores se modernizariam. Ou seja, o progresso técnico e econômico liquidaria os vínculos da tradição, e o país se instalaria num processo de mudanças que acabaria por estabelecer e consolidar a democracia representativa (Nun, 2001, p.12-13).

A literatura sociológica brasileira dos anos sessenta e setenta discutiu a natureza e a especificidade do "desenvolvimento capitalista periférico" e seus efeitos sobre a matriz das relações sociais excludentes, a exemplo das teorias da "massa marginal" [Nun, 1969], da "teoria da dependência" [Cardoso; Faletto, 1970], e da crítica às "teses dualistas", formulada por Oliveira [1972] e implícitas nas noções de "subdesenvolvimento" e de "modernização" da Cepal, etc.

Reconhecendo a heterogeneidade e a coexistência de diferentes modos de produção na formação histórica de sociedades latino-americanas e sustentado na interpretação marxiana do materialismo histórico, Nun, no artigo "Superpopulación

${ }^{14}$ Posição hoje superada pelas teses liberais, e de caráter normativo - do "empreendedorismo" (Joseph Shumpeter), do empoderamento, empowerment (John Friedmann), ou da tese de "capacitação dos pobres" na luta contra a pobreza (Amartya Sen) -, entendidas como promotoras de emancipação e autonomia dos sujeitos na promoção do desenvolvimento local alternativo, ao mesmo tempo também articulado ao desenvolvimento nacional. Significa identificar oportunidades e transformá-las em negócio lucrativo. Shumpeter popularizou o conceito do empreendedorismo como central na sua teoria de "destruição criativa“ do capital, pela capacidade de inovação dos agentes. 
relativa, ejército industrial de reserva y masa marginal" (1969) ${ }^{15}$ distingue a "superpopulação relativa”, como um fenômeno existente em todos os modos de produção, da noção de "exército industrial de reserva”, restrita ao capitalismo. Para Nun, na fase do capitalismo monopolista, a superpopulação relativa, em sua totalidade, deixa de ter essa "funcionalidade". Assim, ele distingue a parte funcional da superpopulação relativa ao capital, que considera como "exército industrial de reserva", e outra, considerada por ele "não funcional" à acumulação capitalista, a qual ele chama de "massa marginal". ${ }^{16}$

Fernando Henrique Cardoso [1969 $]^{17}$ critica as teses de Nun pela ambiguidade metodológica da noção de "funcionalidade" dos sistemas de produção, cujo patamar analítico se distingue da noção de exército industrial de reserva, reveladora da natureza contraditória entre acumulação e exploração do trabalho, e não da "funcionalidade" [adaptação] entre a produção capitalista e as précapitalistas. Para Cardoso, a noção de "massa marginal" de Nun seria mais um conceito heurístico e operacional do que uma "contradição necessária" histórica, inerente às relações entre as classes sociais. Ao se referir à "contradição necessária”, Cardoso considera que a proposta de Nun deixou à margem o caráter conflitual das classes, que diz respeito às condições de exploração e pobreza dos trabalhadores, inerente ao regime de acumulação. Ele admite que esse procedimento poderia se justificar em contextos em que não existam empregos suficientes para todos, ou de expansão do sistema econômico.

15 Texto publicado originalmente na Revista Latinoamericana de Sociología, v.5, n.2, p.178-236, 1969. Nesse texto as referências seguem a republicação do artigo em Nun (2001).

${ }^{16}$ Para Nun (2001, p.24-25), o conceito de exército industrial de reserva foi utilizado por Marx para designar os efeitos funcionais da superpopulação relativa na fase do capitalismo que ele estudou. Nun propõe chamar de massa marginal a parte da superpopulação relativa que, em outras situações, não produz esses efeitos funcionais.

17 No trabalho "Comentario sobre los conceptos de sobrepoblación relativa y marginalidad”, Revista Latinoamericana de Ciencias Sociales, Santiago do Chile, ELAS-ICIS, n.1/2, p.57-76, 1970. Baseamo-nos na sua republicação sob o título de "Crítica de F.H. Cardoso”, em Nun (2001, p.141-183).
No livro Dependência e desenvolvimento na América Latina [1970], Fernando Henrique Cardoso e Enzo Faletto constroem uma perspectiva sociológica sobre o desenvolvimento na América Latina, visando a estabelecer a natureza social e política desse processo, em diálogo com a economia política. "A problemática sociológica de transformação econômica requer a análise das situações em que a tensão entre grupos e classes sociais revele as bases de sustentação econômica e política." (p.37). No capítulo sobre "Subdesenvolvimento, periferia e dependência”, esses autores retornam à questão das "etapas" da transição, discutidas por Prado Junior [1966], com a seguinte formulação "[...] entre as economias desenvolvidas e as subdesenvolvidas não existe uma simples diferença de etapa ou de estágios, do sistema produtivo, mas de posição dentro de uma mesma estrutura econômica internacional de produção e distribuição." (p.3839). Os autores abrem um novo esquema de interpretação para o desenvolvimento, à época, articulando variáveis econômicas às políticas, ou seja, as estruturas de dominação de classes, os conflitos de interesses e as instituições sociopolíticas.

Francisco de Oliveira (1976), na crítica às concepções dualistas e estruturais da CEPAL, distingue a contribuição de Cardoso e Faletto (1970) das outras análises sobre a dependência e a dominação externa.

Fernando Henrique Cardoso e Enzo Faletto elaboram uma teoria da dependência cuja postulação essencial reside no reconhecimento que a própria ambigüidade [sic] confere especificidade ao subdesenvolvimento, sendo a "dependência" a forma em que os interesses internos se articulam com o resto do sistema capitalista. Assim, [esses autores] afastaram-se do esquema cepalino que vê nas relações externas apenas oposição a supostos interesses nacionais globais, para reconhecerem que, antes de uma oposição global, a "dependência articula os interesses de determinadas classes e grupos da América Latina com os interesses de determinadas classes e grupos sociais de fora da América Latina”. (Oliveira, 1976, nota 4, p.70-71)

Sintetizando o debate sobre os limites da teoria da modernização - que opunha o setor moderno ao setor tradicional, atrasado -, um conjun- 
to de estudos avançou no sentido de perceber e explicar a heterogeneidade dos mercados de trabalho brasileiros. Duas perspectivas orientaram essa análise crítica: a primeira é tributária de reflexões de caráter histórico-estrutural dual, voltada para entender a natureza da dominação sobre os países periféricos, o caráter da dependência e a natureza da burguesia nacional em relação aos centros de produção do capitalismo, a exemplo de Nun; a outra tomou como eixo analítico a tese relativa às "contradições fundamentais" inerentes às condições de classe, de exploração da força de trabalho e a concentração da renda na formação da população excedente, como exército industrial de reserva, e o entendimento da dinâmica de estruturação do mercado de trabalho nos países de capitalismo periférico, como categoria crítica do processo de modernização brasileiro (Cardoso; Faletto 1970; Oliveira, [1972] 1976).

Na crítica de Francisco de Oliveira [1972] (1976) às concepções cepalinas, ele esclarece que a perspectiva dualista induzia a uma visão éticofinalista de satisfação das necessidades da população, desconhecendo que a finalidade do sistema é a sua própria reprodução. Considera que o pensamento socioeconômico latino-americano, ao procurar romper com as teses cepalinas de caráter dualestruturalista, e entender a problemática latinoamericana mediante a utilização de um arsenal teção das abordagens marginalista e keynesiana.

Segundo Oliveira, os estudiosos da dependência latino-americana - orientados segundo a relação entre centro e periferia e pela constituição de um "modo de produção subdesenvolvido" -, à exceção da tese de Cardoso e Faletto, deixaram de tratar aspectos relativos às contradições de classes e às estruturas de dominação que conformam o processo de acumulação próprio a países periféricos, como o Brasil:

[...] toda a questão do desenvolvimento foi vista sob o ângulo das relações externas e o problema transformou-se, assim, em uma oposição entre nações, passando despercebido o fato de que, antes de oposição entre nações, o desenvolvimen- to ou o crescimento é um problema que diz respeito à oposição entre classes internas (p.9).

Para o autor, essa discussão teve importância decisiva, desconsiderando a indagação principal: "a quem serve o desenvolvimento econômico capitalista no Brasil?” (Oliveira, 1976, p.10). Assumindo uma interpretação marxiana sobre a formação do exército industrial de reserva, Oliveira critica o modelo de substituição de importações.

$\mathrm{O}$ fato de que o processo tenha desembocado num modelo concentracionista, que numa segunda etapa de expansão vai deslocar o eixo produtivo para a fabricação de bens de consumo duráveis, não se deve a nenhum fetiche ou natureza dos bens, a nenhum "efeito-demonstração", mas à redefinição das relações trabalho-capital, à enorme ampliação do exército industrial de reserva", ao aumento da taxa de exploração, às velocidades diferenciais de crescimento de salários e produtividade que reforçam a acumulação (p.22, grifos do autor).

Assim, Oliveira (p.8) considerava que os conhecidos opositores da CEPAL, no Brasil e na América Latina, tinham quase sempre a mesma filiação teórica marginalista, neoclássica e keynesiana, comprometidos com o status quo econômico, político e social da miséria e do atraso secular latino-americano. E, a respeito da especificidade da expansão do capitalismo, no Brasil e na América Latina, produz uma nova síntese sobre os dilemas da tradição e do capitalismo:
A originalidade consistiria talvez em dizer-se que [...] a expansão do capitalismo no Brasil se dá introduzindo relações novas no arcaico e reproduzindo relações arcaicas no novo, um modo de compatibilizar a acumulação global [...]. Essa forma parece absolutamente necessária ao sistema em sua expansão concreta no Brasil, quando se opera uma transição tão radical de uma situação em que a realização da acumulação dependia quase que integralmente do setor externo, para uma situação em que será a gravitação do setor interno o ponto crítico da realização, da permanência e da expansão dele mesmo. Nas condições concretas descritas, o sistema caminhou inexoravelmente para uma concentração da renda, da propriedade e do poder. (p.28-29, grifos do autor).

Para Oliveira, a conversão de enormes con- 
tingentes populacionais em "exército industrial de reserva” era pertinente e necessária, do ponto de vista da reprodução do capital, porque atendia, de um lado, ao cálculo econômico empresarial num horizonte médio, enquanto, de outro, a legislação trabalhista igualava, reduzindo o preço da força de trabalho, ao invés de incrementá-la.

As características assumidas pelo modelo de desenvolvimento brasileiro, especialmente no contexto da modernização autoritária realizada no período militar, envolveram intensos debates e críticas sobre o caráter conservador dessa modernização. Esse caráter se vincula e se restringe ao progresso técnico e ao crescimento econômico altamente concentrador, sem mudança significativa da distribuição da renda e das relações políticas e sociais assentadas numa cultura política patrimonial e autoritária. Essa crítica singulariza a questão social em países caracterizados por extrema pobreza, altos índices de desigualdades sociais e por um Estado de Bem-estar incompleto, como o Brasil, que deixou à margem da cidadania a maioria dos trabalhadores brasileiros, fora da proteção dos direitos do trabalho, reduzidos à condição de reprodução da vida no nível de pura sobrevivência. ${ }^{18}$

\section{A herança da modernização conservadora: ampliação das desigualdades socioeconômicas e culturais}

O debate sociológico do modelo de desenvolvimento diz respeito ao tema da distribuição, ou da justiça distributiva, o que implica pensar como os resultados da economia são apropriados socialmente, questionando "como" se está crescendo e "para quem" se dirigem os resultados dessas

${ }^{18}$ Acompanha esse processo todo um debate sobre a natureza do excedente social de trabalhadores. A crítica a algumas categorias, como desocupação, subemprego e subocupação, setor informal, renda inadequada etc., permitiu avançar no reconhecimento de indivíduos submetidos a essas ocupações como "trabalhadores": trabalhadores por conta própria, autônomos e independentes. Essa nominação tem efeito simbólico de reconhecimento deles como sujeitos do trabalho e permite, metodologicamente, ultrapassar aspectos duais e atributos ou designações negativas, implícitos nas anteriores. Essa análise foi objeto do capítulo IV do livro de Ivo (2008). políticas e os custos desse crescimento, do ponto de vista da qualidade do bem-estar dos cidadãos. Portanto, a modernização conservadora e excludente contém dimensões sociais, políticas e institucionais legitimadoras do regime de concentração de riqueza, o que, no caso brasileiro, produziu uma massa de excluídos e padrões de desigualdade de renda extremamente elevados entre trabalhadores, grupos e (ou) regióes.

A modernização conservadora, que marca a sociologia do desenvolvimento até os anos oitenta, aponta um conjunto de fatores determinantes da iniquidade no Brasil: ${ }^{19} \mathrm{a}$ longa história do escravismo e do latifúndio, que sedimentou relações profundamente verticais e desiguais, hierarquizadas; o caráter centralizador, patrimonialista e autoritário da cultura política brasileira, permeado por relações clientelistas que se alternam e (ou) se complementam com o círculo burocrático (Nunes, 1997); o caráter dependente do capitalismo periférico; a natureza restrita da política de seguridade social, decorrente de uma inclusão imperfeita da massa trabalhadora aos empregos protegidos com a persistência de amplos contingentes de trabalhadores informais, excluídos com suas famílias de um sistema de proteção e de Direitos sociais; e o enorme volume da pobreza, como fenômeno de massa (Lautier, 1995). São fatores que, articulados, contribuem para a formação de um massivo e histórico processo de exclusão das famílias de trabalhadores, dos benefícios do desenvolvimento brasileiro (Ivo, 2001, 2008).

As razões da persistência da iniquidade da estrutura social brasileira não são, portanto, exclusivamente econômicas, mas se referem ao padrão altamente concentrador da renda e do poder, esse último garantido por uma herança lusitana de relações políticas e sociais autoritárias, que,

${ }^{19}$ Nunes (1997), na Gramática Política do Brasil, destaca quatro fatores: o clientelismo, o patrimonialismo, o corporativismo e o insulamento burocrático. Esse último é encaminhado pelo Estado autoritário. Jessé de Souza (2003, p.97) critica o uso das categorias personalismo, familismo e patrimonialismo para explicar as mazelas sociais nos países periféricos, porque, car as mazelas sociais nos países periféricos, porque,
segundo ele, elas expressam uma visão "cultural essencialista”. 
desde a época colonial, mantiveram à parte "homens livres", moradores do campo e das cidades, considerados como "desocupados", "vadios", "vagabundos", "marginais" ou "resíduos”, frente aos setores hegemônicos da economia.

JoséMurilo deCarvalho (2000) aproxima a transição da questão social brasileira à experiência conservadora da Alemanha, "onde houve aliança dos senhores de terra com o Estado e os industriais” (p.28).

\section{INFLEXÕES DO PARADIGMA DO DESENVOL- VIMENTO NOS ANOS OITENTA E NOVENTA: a democracia e os ajustes estruturais}

\section{O projeto de democratização nacional e a emer- gência de novos atores sociais}

A década de oitenta, considerada a "década perdida” da perspectiva do projeto modernizador, pela estagnação econômica dos países da América Latina - com retração da produção industrial, volatilidade dos mercados e redução do ritmo do crescimento -, expressa uma crise do modelo e a emergência de novos atores no cenário nacional, orientada por um processo de resistência política e pressões para reconhecimento de direitos da cidadania. Do ponto de vista político, o período caracterizou-se por um alto nível do conflito social, gênero; de ambientalistas, entre outras) em redes também nacionais e pontos da agenda local, que se entrecruzam com as condições de classe e de reprodução das camadas populares trabalhadoras, em níveis de extrema pobreza.

A transição brasileira, nesse contexto dos anos 80, orientou-se pelas lutas para expansão dos direitos da cidadania, num contexto de mobilização nacional por democratização da sociedade e das instituições políticas de um Estado de direitos e liberdade de expressão. A sociedade civil se diferenciou sob a influência de novos atores sociais: o novo sindicalismo, os novos movimentos sociais e as pressões de organizações não-governamentais, que se expandem desde 1986, os intelectuais, a Igreja, os partidos de esquerda de oposição ao regime militar, a imprensa, e, também, a formação de um novo empresariado paulista moderno, produtor de bens de capital. Esse segmento de classe constituiu-se especialmente no governo Geisel, e começa a se autonomizar na formulação crítica de políticas e defesa de interesses "nacionais". ${ }^{20} \mathrm{O}$ Estado desloca-se do seu papel racionalizador da mudança e do progresso técnico-industrial para atuar prioritariamente como mediador dos conflitos dos distintos interesses da sociedade civil, (empresários, trabalhadores e movimentos sociais), que pressionam por direitos civis, políticos e sociais. A alta mobilização dos atores sociais e partidos encaminhou mudanças institucionais do Estado de direito, que se consolidaram na Constituição Brasileira de 1988, especialmente na universalidade de direitos sociais e de participação da cidadania.

\section{Na contramão do projeto nacional: o diagnós- tico conservador da reforma do Estado dos anos noventa}

Na contramão da historicidade dos atores sociais em luta, no Brasil como em outras socieda-

${ }^{20}$ Um exemplo seria da Gazeta Mercantil e do Pensamento Nacional das Bases Empresariais, criado em 1987, cuja missão é articular empresários para tornar o país economicamente mais desenvolvido, socialmente mais justo e politicamente mais democrático. 
des, observa-se, no âmbito internacional, uma ruptura do pacto redistributivo que sustentou o Estado de Bem-estar em muitos países e cujos efeitos sociais, nos anos 90 , mostraram-se mais graves nas sociedades latino-americanas, devido ao caráter ainda incompleto dos regimes de bem-estar social nesses países.

A oposição dos liberais ao pacto redistributivo dos regimes de bem estar não é nova e expressa tensões clássicas entre forças liberais e socialistas, que postulam por maior ou menor liberalização de mercados, maior ou menor grau de interferência do Estado na regulação do capital e em favor da "desmercadorização"21 da força de trabalho, questões que integram o conflito distributivo (Ivo, 2007).

A crítica liberal ao modelo de bem-estar, na década de 50, considerava que as políticas redistributivas eram incompatíveis com o crescimento econômico estável e representavam pressão inflacionária de difícil controle para os Estados nacionais (Perrin, 1969). O crescimento acelerado da economia até os anos setenta neutralizou essas criticas. Na contramão da crítica dos liberais, na década de sessenta, setores da esquerda, dos trabalhadores e das diversas minorias organizadas em matéria de "igualdade" e direitos, criticavam o regime, exigindo expansão de benefícios e cobertura de direitos civis e sociais, pela pressão dos movimentos sociais. No Brasil, a expansão desses movimentos ocorreu especialmente nas décadas de 70 e $80 .{ }^{22}$

Odiagnóstico conservador da governabilidade para a América Latina ${ }^{23}$ (Achard; Flores, 1997),

${ }^{21}$ Corresponde à expressão "decommodification“ usada por Gosta Esping-Andersen (1990), que significa o acesso dos trabalhadores a seguros e prestações sociais, baseados em direitos e políticas sociais, que representam uma socialização parcial da economia.

${ }^{22}$ Essa tendência teve efeitos sobre países em desenvolvimento e se expressou em intensas mobilizacões sociais na década de 70 e 80 . A ação desses movimentos traduziu-se na expansão de direitos sociais básicos de cidadania inscritos na Constituição Brasileira de 1988, como a Previdência especial rural e o Benefício da Prestação Continuada, além de benefícios dirigidos aos direitos das minorias.

${ }^{23}$ Sobre o detalhamento do diagnóstico da governabilidade, ver: Valladares e Coelho, 1995; Melo, 1996; Achard e Flores, 1997; Diniz, 1997; Boschi, 1999; Ivo, 2001. A perspectiva "conservadora” refere-se à tradução política da liberação econômica (mercados livres) com redução a intervenção do Estado no âmbito da economia. formulado em meados da década de setenta pelas agências multilaterais, aponta como fatores determinantes da crise: a crise fiscal provocada por demandas crescentes; excesso de democracia, provocando crise de autoridade; e o provincianismo dos Estados nacionais, fatores que, da perspectiva neoliberal, dificultavam a livre circulação de capitais. Esse diagnóstico consta do relatório de Michel Crozier, ${ }^{24}$ Samuel Huntington e Joji Watanuki The Crisis of Democracy, encomendado pela Comissão Trilateral em 1975, voltado para orientar interesses do capitalismo global, articulando os interesses dos países do Norte (especialmente Estados Unidos e Europa) e Ásia (Japão). Ele orientou as recomendações do Consenso de Washington e as reformas e ajustes do Estado, em diversos países, nos anos 90. Os autores desse relatório consideram a incontrolabilidade da crise fiscal nos centros do capitalismo avançado como fator inflacionário e de ingovernabilidade dos Estados nacionais, provocado pelo welfare. Sugerem medidas restritivas à democracia pela reforma das instituições políticas sob hegemonia do mercado, em favor da estabilidade econômica e do combate à inflação.

Em 1981, a Organização para a Cooperação e o Desenvolvimento Econômico - OCDE (Organization for Economic Co-operation and Development-OECD), ${ }^{25}$ que representa interesses dos países ricos, reforça a tese original que opõe políticas redistributivas (de bem-estar) aos objetivos do crescimento econômico, entendendo que a estagnação do crescimento dos anos 80 , as altas taxas de inflação e o crescente desemprego resultavam diretamente da crise fiscal pelo excesso de de-

${ }^{24}$ O capítulo sobre os Estados Unidos foi escrito por Samuel Huntington, um economista americano conservador. $\mathrm{O}$ capítulo sobre a Europa Ocidental é da autoria do sociólogo francês Michel Crozier formulador das bases da ação estratégica da Sociologia das Organizações; e o capítulo sobre o Japão é da autoria do sociólogo japonês Joji Watanuki, autor de reflexões sobre a natureza do regime de acumulação na sociedade japonesa.

${ }^{25}$ Organização que articula o "grupo dos ricos”, ou seja, 37 países de alta renda e índices de desenvolvimento humano que se orientam segundo princípios da democracia representativa e da economia do livre mercado. Foi criada em 1960, sucedendo à Organização Europeia para a Cooperação Econômica (OECE), responsável pela implementação do Plano Marshall (1947) de reconstrução do continente europeu, no pós-guerra. 
mandas sociais, sem capacidade de processamento pelos Estados nacionais.

O esgotamento do regime de acumulação fordista no centro do capitalismo mundial repercutiu sobre as formas de regulação econômica e política, especialmente sobre o papel do Estado nacional como indutor do desenvolvimento e responsável pela proteção social universal, priorizando mudanças institucionais nos Estados em defesa da estabilidade, nos anos noventa, com ênfase em ações estratégicas empreendidas por corpos intermediários, tais como família, associativismo e desenvolvimento local, como caminho para enfrentar as crises cíclicas do mercado. O efeito dessas mudanças, do ponto de vista social, foi mais grave em países como o Brasil, dadas as enormes e históricas desigualdades sociais e o caráter incompleto das políticas de bem-estar social.

Essa transição alterou as responsabilidades do Estado nacional como promotor e regulador do desenvolvimento, observando-se uma desconcentração do poder do Estado nacional, reorientado por reformas em favor do mercado, através das privatizações, e operando a descentralização de políticas sociais com ênfase nas dinâmicas locais, na passagem de responsabilidades públicas para a esfera da sociedade civil, com base no modelo de "parcerias público e privado", e, em termos de Seguridade e proteção, reorientando o princípio do Estado (social) protetor de caráter universalista para um Estado de assistência focalizada sobre os mais pobres, etc.

No plano econômico, priorizaram-se políticas monetárias voltadas para garantir estabilidade e condições necessárias à liberalização e mobilização de capitais, especialmente financeiros. Um dos atores internacionais centrais dessa mudança é o Fundo Monetário Internacional (FMI), ${ }^{26}$ que, na década de noventa, orienta e controla os Estados nacionais

${ }^{26}$ O Fundo foi criado em 1944 para evitar desequilíbrios no balanço de pagamento dos países membros, atuando na formulação de uma política monetarista e no monitoramento dos programas de ajustes estruturais, na assistência técnica e treinamento aos países membros. Nos anos noventa, transformou-se em ator internacional central da nova ordem neoliberal no monitoramento e controle das contas públicas nos diversos países, em função da administração da dívida externa. na aplicação de políticas de austeridade e ajustes fiscais, e de reforma do Estado, sob o argumento da administração da dívida externa (Osmond, 1998).

Na década de noventa, o conflito se expressa, portanto, entre os interesses do projeto de democratização nacional - formulado e conduzido pelos diversos atores nacionais na década de oitenta, em favor dos direitos da cidadania brasileira - e os atores internacionais, agências financeiras e de desenvolvimento associadas aos Bancos Centrais e a setores comprometidos com a política monetarista, a reforma e o ajuste institucional do Estado.

Essa reforma, em prol de um modelo de Estado gerencial, assentado em critérios institucionais de eficiência e competitividade, representa, na realidade, um rearranjo interno de atores e instâncias de decisão e interesse, sob a hegemonia de políticas monetaristas, e envolveu aplicação rigorosa do ajuste fiscal, sobretudo nos governos dos países latinoamericanos. Tal orientação aprofundou a ruptura do pacto nacional-desenvolvimentista (entre Estado, elites empresariais e trabalhadores assalariados urbanos), que vigorou até os anos 70, e neutraliza o papel do Estado nacional como processador de conflitos, esvaziando parte das lutas encaminhadas na década de oitenta por atores da sociedade civil organizada e expandindo a pauta de políticas sociais orientadas também para o reconhecimento de direitos civis. O Estado nacional reformado, que se reestrutura na década de 90, reforça a função coercitiva do Executivo como gestor do ajuste fiscal e reconverte os princípios universalistas da Constituição de 88, relativo às políticas de seguridade de direitos básicos universais, em ações de combate à pobreza pela via de programas estratégicos de assistência social focalizada.

Essa transição desloca a "temática do conflito" (redistributivo) relativo às classes e ao padrão da integração social para "o tema dos procedimentos gerenciais” da eficácia da alocação de benefícios, transferindo princípios estratégicos do mercado (eficiência e competitividade) para o Estado-gerente reformado, executor das metas de estabilidade e controle das contas públicas, exercido por uma burocracia estatal moderna e eficiente, que, 
nesse contexto, passa a se constituir como um dos atores fundamentais dessa transição.

A concepção do governo federal, no final da década de 80, considerava que o dilema da redistribuição e da "inclusão social" fora sustentada, no Brasil, com base em políticas monetaristas e planos anti-inflacionários, ${ }^{27}$ realizados indiretamente pelo Plano Real. Esse Plano significou aumento real do Salário Mínimo, o que favoreceu especialmente pessoas com renda mais baixa, facultando sua maior integração aos mercados e em melhores condições de seguridade econômica, em termos reais. À sociedade civil, nessa nova ordem, coube a responsabilidade pública do controle social, a fiscalização das contas públicas e a corresponsabilidade na implantação de políticas sociais através dos diversos conselhos e arenas públicas, além da busca de oportunidades competitivas no âmbito produtivo.

\section{A local governance (anos 80-90): uma nova categoria normativa da ação prática para 0 desenvolvimento}

Diante dos efeitos perversos da aplicação das políticas de ajuste fiscal e da crise de representação dos atores, especialmente urbanos, o Banco Mundial, desde 1989, introduziu, em seus relatórios sobre o desenvolvimento, a noção de local governance (World Bank, 1992). Trata-se de um espaço estratégico de intermediação e ação concertada de interesses contraditórios entre os diversos atores da sociedade civil, do mercado e do Estado, através de conselhos, comissões e fóruns. Essa ação concertada constitui-se num espaço aberto à construção de arranjos entre diferentes agentes sociais, privados e públicos, na formulação de projetos de desenvolvimento. Esse modelo reconhece que as possibilidades competitivas dos projetos de desenvolvimento, em distintas escalas, dependem da coalizão e do acordo entre os atores. Por outro lado, considera a possibilidade de projetos de desenvolvimento pela capacidade de coordenação entre Estado, mercado e sociedade, em cada situação, ${ }^{27}$ Ver entrevista de Fernando Henrique Cardoso, publicada por Achard e Flores (1997, p.80-90) escala e temporalidade específica.

O Presidente do Banco Mundial, numa fala de agosto de 1991 (World Bank, 1992), considerava que a estabilidade política e econômica não era suficiente para o desenvolvimento. Sugere um conjunto de dispositivos normativos de "bom governo" " "boas práticas", de caráter moral (luta contra a corrupção, contra o familismo amoral, o corporativismo e o clientelismo, etc.), tendo em vista a construção de um novo consenso de Estado eficiente. Tais dispositivos implicam medidas institucionais de transparência das contas públicas, eficiência administrativa e competitividade, afastando as "más condutas" e o legado da ordem tradicional das relações políticas corporativas e protecionistas do Estado com setores do empresariado e dos trabalhadores.

Com base nas normativas das agências multilaterais, formulam-se orientações práticas e transmitem-se novas modalidades de arranjos para atores públicos e privados, como as parcerias público-privadas, a criação de arenas públicas, a descentralização das ações, accountability, etc. Tais arranjos são formadores de consensos parciais, destacando as (supostas) virtudes do Estado reformado na construção de ações preventivas contra "condutas indesejáveis", resultantes da herança de uma cultura política autoritária, patrimonialista, clientelista e corporativa.

O grande equívoco situa-se na tradução de questões políticas em problemas de gestão. Ao assentar-se sobre princípios morais de "boa conduta" e não em valores universais da democracia e da política, reitera-se um raciocínio binário e dual entre velhos e novos atores, desconhecendo-se a permeabilidade ea capacidade de adaptação dos atores da "tradição e da modernidade",nocampo institucional. Noâmbito das práticas, os agentes são sujeitos com capacidade estratégica para pactuar e atualizar seus interesses, com permeabilidade dos velhos atores em "novas práticas", como a adesãoà luta contra a pobreza por setores de oligarquias tradicionais, ${ }^{28} \mathrm{e}$ a adoção das "velhas práticas”, envolvendo também partidos de esquerda.

${ }^{28}$ A criação do Fundo Nacional de Combate à Pobreza pelo então senador do PFL, Antônio Carlos Magalhães. 
A epistemologia emancipatória e participativa para um novo paradigma de desenvolvimento

Esse movimento de desconcentração do Estado e de emergência desses novos atores e movimentos, na década de oitenta, é acompanhado, também, de uma crítica epistemológica ao caráter dedutivo e estrutural da noção de desenvolvimento como "um modelo universal" e único, regido pelo mercado e pela democracia liberal (ou modelos autoritários), como se só existisse um tipo de regulação para os conflitos sociais em todas as sociedades e em todos os seus segmentos.

Essa crítica buscava superar a perspectiva homogeneizadora do desenvolvimento das décadas de 50 e 60, como modelo universal, e é pensada também por alguns "[...] como um projeto de humanidade solidária inerente a todos os atores sociais com capacidade autotransformadora para o desenvolvimento" (Prieto, 2010, p.82). Na realidade, parte dessa epistemologia se constitui nas lutas por emancipação dos novos movimentos sociais (NMS) por igualdade e reconhecimento das diversidades, frente às múltiplas formas de exclusão social e cultural (de gênero, de raça, de religião, de gerações etc.), associadas às lutas sindicais e dos trabalhadores por justiça redistributiva. Essas lutas pressionaram por políticas públicas de acesso a bens públicos e fundiários (movimentos dos sem-terra, movimentos urbanos pela moradia, sem-teto, etc.), por melhoria das condições de vida (movimentos contra a carestia, entre outros) e por acesso a serviços públicos urbanos, etc. (Gohn, 1985; Jacobi, 1989; Sherer-Warren, 2000, 2003).

A superação dessa polarização tem sido encaminhada, ao menos, por duas perspectivas. Primeiramente, encaminha-se para um esforço metodológico de transversalidade, no sentido de articular as dimensões de trabalho e classe, que envolvem redistribuição, com dimensões estratificadas das desigualdades e vulnerabilidades sociais, em termos de atributos socioculturais (escolaridade, raça, gênero gerações e território), na dinâmica de conformação dos mercados de trabalho.

Os autores Axel Honneth [1992] 2002 e

Nancy Frazer (1997), da teoria social crítica renovada da Escola de Frankfurt, encaminham a superação da polarização das pautas redistributivas, inerente à noção marxiana da classe social, com as lutas por reconhecimento, associadas à dimensão weberiana do status. A. Honneth, fazendo das normas implícitas do reconhecimento o fundamento dos vínculos sociais, produz as bases de uma legítima crítica social (Géguen; Malochet, 2012, p.46). Nancy Fraser considera que o retorno à teoria do reconhecimento ocorreu pela ênfase cultural das sociedades contemporâneas (cultural turn). Para a autora muitas reivindicações de justiça não exigem apenas melhorias econômicas, mas o reconhecimento de identidades e diferenças culturais. Ela, no entanto, critica as teorias do reconhecimento restritas às dimensões culturais, morais e identitárias, por desconhecerem a dimensão redistributiva da justiça. Frazer considera que a questão da justiça, nas sociedades contemporâneas, caracteriza-se pela articulação de dois tipos de "injustiça": a do tipo socioeconômico, manifesta pela exploração do trabalho e pelas condições de reprodução material; e as do tipo cultural e simbólico, submetidas a formas de dominação cultural, desqualificação e invisibilidade social (1997).

A construção dos Fóruns Mundiais na luta antiglobalização, nos anos 2000, aparece como arena ampla e emblemática de articulação de redes de atores sociais em escala internacional. As organizações não governamentais e outros movimentos sociais comprometidos com a formulação de novos entendimentos e alternativas ao desenvolvimento transnacionalizam as redes de inúmeros movimentos sociais na crítica ao regime de acumulação globalizado e ao "modelo único" (Sherer-Warren, 2000, 2003; Gohn, 1985, 2008).

Uma segunda dimensão da transversalidade é observada a partir da dimensão do território, dos agentes e dos destinos locais nas suas interfaces e arranjos no âmbito das escalas produtivas dos grandes projetos ou de políticas locais. Para outros, as alternativas do "modelo" visam a considerar a permeabilidade de arranjos entre atores na construção de pautas políticas locais ou regionais, em 
cada país, de acordo com suas singularidades históricas, tal como analisaram Danielle Leborgne e Alain Lipietz para os contextos pós-fordistas na Itália (Leborgne; Lipietz, 1991a, 1991b), e José Ricardo Ramalho (2005), que discute a formação de novos padrões de participação e a formação de redes sociopolíticas que se constituem nas localidades onde ocorrem as atividades industriais.

Esses arranjos mobilizam atores distintos, quer se considerem áreas metropolitanas, quer se trate das tipicamente rurais. Nas áreas metropolitanas, o desenvolvimento local contempla arranjos e interesses entre empresas industriais, trabalhadores e agentes locais. Boschi e Gaitán (2008) destacam que alguns acordos têm grande importância na geração de bem estar para os assalariados, a exemplo dos " [...] acordos institucionais do mercado de trabalho [...] por meio das negociações entre os diversos atores envolvidos, no desdobramento de estratégias de qualificação da mão de obra." A singularidade e inovação desses acordos explora a dimensão participativa de empresários e trabalhadores "além da fábrica" (Ramalho e Santana, 2003), considerando os destinos regionais, a exemplo da análise sobre a experiência da Comissão Tripartite do ABC paulista (Ramalho; Jacome, 2010) e dos distritos automotivos da baixada Fluminense (Jacome; Cunha; Ramalho; Santana, 2006). Por outro lado, o impacto de grandes projetos nacionais tem efeito no âmbito local e regional, em relação à estruturação econômica e à questão social e ambiental, mobilizando agentes (econômicos, sociais e políticos) em diversas escalas de governança, que passam por arranjos em diferentes níveis. Esses espaços contêm a superposição de interesses contraditórios de atores nos limites do território e constituem campos alternativos de discussão e construção de projetos de desenvolvimento sustentado, em diferentes escalas (local, nacional e global), que envolvem movimentos contraditórios de integração ou exclusão, ou seja, o destino das populações tradicionais e locais preexistentes e a emergência de novos atores de grandeza e força distintas sobre um mesmo território.

Do ponto de vista do desenvolvimento territorial de base rural, Wanderley (2000) mostra como a opção prioritária por políticas agrícolas gerou problemas de exclusão de áreas e grupos socialmente marginalizados, e a necessidade consequente de integração de espaços e populações na dinâmica econômica e social, assegurando a preservação dos recursos naturais como patrimônio de toda a sociedade, além da superação das desigualdades e da pobreza.

Assim, do ponto de vista político, o território incorpora um movimento de mão dupla. De um lado, ele se constitui como um espaço de realização de projetos coletivos e, do outro, ele é o lugar de intervenção das políticas, dos poderes públicos e dos agentes produtivos. Dessa perspectiva, um projeto de desenvolvimento local, resulta da convergência das demandas e iniciativas locais e da interferência dos grandes projetos nacionais e supranacionais (Wanderley, 2000). É na tensão desses arranjos e escalas entre diferentes agentes que se conformam e constroem as tendências e possibilidades do (novo) desenvolvimento, no âmbito dos lugares e do território. O modelo de desenvolvimento territorial oficial, promovido pelo Ministério do Desenvolvimento Social e Combate à Fome (MDS), concilia combate à pobreza, segurança alimentar e nutricional, proteção ambiental e geração de renda. O território torna-se, portanto, "um novo espaço de construção de projeto e articulação de políticas públicas em parceria com estados, municípios e sociedade civil” (MDS, 2012). O processamento dos conflitos em escala global opera a passagem dos projetos de desenvolvimento local e dos interesses particulares de múltiplos atores para escalas e entendimentos mais globais. Essa passagem não significa que o desenvolvimento nacional se constitua do somatório de iniciativas locais, mas da capacidade de prevalência e força de agentes de orientar esses projetos e as forças em escalas mais ampliadas. Depende, portanto, da capacidade do Estadona relação com países, mas também da interface da rede de atores sociais nacionais e globalizados. $\mathrm{O}$ desafio posto pelas novas epistemologias é de ultrapassar dimensões particularistas na direção de questões universais e globais, sem o risco da capi- 
tulação dos sujeitos pelo universalismo econômico liberal do mercado, ou pelo essencialismo dos movimentos identitários.

A perspectiva reformista do Estado, dos anos 90, orientada para a desconcentração do Estado em benefício de políticas descentralizadas, também reforça o papel do local e da microeconomia na sustentabilidade de um desenvolvimento endógeno, econômico e social, local e regional, como possibilidade inovadora e de governança local.

Essa dupla matriz - que caminha em paralelo e segundo marcos políticos e ideológicos distintos, ou seja, aquela dos novos movimentos sociais emancipatórios e a dos dispositivos normativos da reforma institucional - produz uma "convergência contraditória”, que expressa movimentos de hegemonia e contra-hegemonia, nos quais a polissemia inscrita nas categorias intermediárias de governança, capital social, capital humano, redes sociais, inovação, etc. expressa um "giro linguístico" (Ianni, 1999) pelo qual essas noções são mediadoras da transformação das relações sociais e de poder.

Na linha institucional, na década de noventa, alguns autores (Coleman, 1990; Putnam [1994] 1996; Baas, 1997; Joseph, 1998; Bullen; Onyx, 1998 , etc.) destacam os determinantes culturais e societários como lastro para o desenvolvimento redistributivo, podem induzir uma perspectiva “comunitarista romântica”, afastada da dimensão do conflito e das instituições do Estado. Ao considerar o mercado como a via principal da integração social, os processos cooperativos podem ocultar relações assimétricas, deatores hegemônicos dofinanciamento, transferindo os riscos dos empreendimentos e do fluxo financeiro para os setores populares.

A ideia de sustentabilidade associada ao desenvolvimento endógeno anuncia uma nova utopia de equilíbrio entre crescimento econômico, equidade social e proteção do meio ambiente (Lebauspin, 2010), mas mostra também a complexidade e a polissemia implícitas nesses processos, que podem "fetichizar o lugar do conflito dos agentes, em favor do mercado.

Para alguns (Veiga, 2005; Sachs, 2002, 2004), a sustentabilidade do desenvolvimento, combinada ao paradigma da igualdade e da proteção social, anuncia uma nova utopia da sustentabilidade, capaz de agregar projetos coletivos. Assim, a noção de "desenvolvimento sustentável", desde fins do século XX, vem se constituindo num paradigma aglutinador de projetos críticos ao modelo de crescimento econômico, associando a ele a defesa do meio-ambiente e o princípio da equidade social, e recolocando o tema da integração social pela via da luta contra a pobreza como condição fundamental do novo desenvolvimento sustentado. ${ }^{29}$

\section{A AGENDA DA INTEGRAÇÃO SOCIAL VIA MERCADO NO PÓS-CONTEXTO DE WA- SHINGTON}

Esta parte analisa as vias de encaminhamento da integração social no contexto dos anos dois mil, orientadas pela agenda internacional do combate à pobreza, que considera dois processos: a mobilização dos pobres na luta contra as suas condições de po-

${ }^{29}$ O documento final da Rio+20 O Futuro que Nós Queremos reafirma esses princípios, que enfatizam promessas para avançar para uma "economia verde", que freie a degradação do meio ambiente, combata a pobreza e reduza desigualdades, que não atendeu às expectativas das ONGs por faltar comprometimentos reais sobre os meios e recursos para viabilizar essas transformações. 
breza, com base num empreendedorismo social, ea via compensatória da transferência de renda a famílias em condições de extrema pobreza. Qual o alcance do ponto de vista da desmercadorização, inerente à regulação do Estado com base nas políticas sociais?

\section{A agenda para os "pobres viáveis": o empreendedorismo como via de superação da pobreza nos anos 2000}

A inserção dos países na dinâmica da acumulação globalizada dificultou a conciliação das tarefas regulatórias do Estado nacional como provedor do desenvolvimento com equidade, num ambiente democrático. Os efeitos dessocializadores (desemprego, precarização, insegurança e empobrecimento de setores médios urbanos) gerados pela reestruturação produtiva e a aplicação rigorosa do ajuste fiscal pressionaram os liberais para uma revisão crítica quanto à temática da integração. Aí se insere o que estamos chamando de pós-consenso de Washington, priorizando a agenda internacional "da luta contra a pobreza", nos anos 2000. Ela integrou os Objetivos do Milênio (2000) formulados pelo Programa das Nações Unidas para o Desenvolvimento (PNUD), que estabeleceu metas para os países membros de: acabar com a extrema pobreza, promover a igualdade entre os sexos, erradicar as doenças e fomentar as bases de um desenvolvimento sustentável até 2015, entre outros objetivos.

As agências multilaterais no combate à pobreza têm se orientado segundo as teses liberais de Amartya Sen. Na crítica à abordagem economicista da pobreza restrita à insuficiência de renda, ele propõe a definição da pobreza como "privação de capacidades". Seu diagnóstico sugere a mobilização e o poder dos "pobres" no enfrentamento da sua própria condição de pobreza. Essa tese reforça a perspectiva emancipatória de autonomia e responsabilidade individual dos sujeitos em condição de pobreza, supondo a transformação dos indivíduos "pobres" da condição de "sujeito passi- vo" para a de "sujeito ativo", protagonista da mudança social [mobilidade]. Isso implica, para Sen, o acesso e o desenvolvimento de capacidades estratégicas das camadas populares.

Essa tese orienta os relatórios das Nações Unidas (PNUD, 1997) quanto a uma nova perspectiva do desenvolvimento social e humano, e dá base para a construção de metodologias de mensuração da pobreza segundo "Necessidades Básicas", ${ }^{30}$ o Índice de Desenvolvimento Humano (IDH), induzindo políticas públicas que enfatizam o acesso dos "pobres" a capacidades básicas (educação, saúde, poder, etc.). Acompanhando a perspectiva de Sen, o PNUD definiu, na década de 90, o "desenvolvimento humano" como um processo de: alargamento das escolhas pessoais em termos de acesso à vida longa e saudável; aquisição de conhecimentos; e acesso a recursos necessários a um padrão de vida adequado. Agregou a essas escolhas valores políticos e humanitários, como: liberdade política, direitos humanos e oportunidades dos indivíduos e cidadãos serem criativos, fomentando a "inovação".

Esse paradigma assenta-se na perspectiva liberal de autonomia do sujeito "empoderado" - o "pobre" - e não se refere às condições estruturais determinantes da pobreza. Ele tem influenciado a concepção das políticas sociais contemporâneas, com base nos paradigmas de capital humano, do capital social, local governance, que operam o mito do desenvolvimento exclusivamente pela individualização da capacitação dos "pobres" na luta para a superação de sua própria condição de pobreza.

Essa tese traz uma tautologia implícita: converte a inserção individual dos pobres no mercado (como produtores e consumidores) em "virtude emancipatória”. Reorienta os precários bens disponíveis das famílias populares (casa, terra e

${ }^{30} \mathrm{O}$ Índice de Desenvolvimento Humano (IDH) agrega indicadores sintéticos de educação, saúde (expectativa de vida ao nascer) e renda, possibilitando comparação entre países e regiões. Ele classifica os países segundo o grau de desenvolvimento humano, em três blocos: aqueles com alto desenvolvimento humano (países desenvolvidos); os de médio desenvolvimento humano (países em desenvolvimento) e os que apresentam baixo desenvolvimento, situação típica dos países subdesenvolvidos, segundo o PNUD. 
trabalho) em "ativos" e "bens de capital" do empreendimento, orientados para superar sua condição de vulnerabilidade social e pobreza. Segundo o Banco Mundial, à mobilização desses "ativos" (propriedades) - que, em realidade, se constituem em recursos de sobrevivência dos trabalhadores do setor informal -, agregam-se outros "capitais" sociais e culturais, segundo Moser (1996), como a solidariedade familiar e as redes comunicativas, consideradas pela economia popular como "oportunidades" no encaminhamento das soluções para as condições de pobreza. Ou seja, as formas de resistência dos trabalhadores autônomos da economia informal são ressignificadas como "virtudes do capital".

A estratégia orientada para a microeconomiaé a via liberal para os "pobres viáveis", aqueles com possibilidade de se transformar em "cidadãos empreendedores e consumidores", pela via de integração ao mercado. Sem desconhecer a potencialidade dos empreendimentos solidários e da microeconomia no fomento ao mercado interno e mesmo a superação de situações de pobreza, a tese da auto-organização estratégica do setor popular ativo transforma "os pobres viáveis", aqueles inseridos no mercado, em agentes financeiros e consumidores no âmbito local, pelo acesso ao crédito e ao consumo, assumindo também os riscos do endividamento no médio prazo. Portanto, a mobilização das variáveis senso de Washington orienta-se pela aplicação dos programas focalizados de transferência de renda, como "assistência aos mais pobres". A reorientação da política social centrada no combate à pobreza, por essa via, busca reduzir os efeitos adversos dos ajustes estruturais e da reestruturação produtiva, institucionalizando-se à margem do campo da proteção social. ${ }^{31}$

O desenho da nova política, no contexto de hegemonia neoliberal, implicou distensão da relação pilar entre proteção social e emprego, rompendo o modelo que caracterizou a construção parcial do Estado social. ${ }^{32}$ Essa mudança se fez através de um novo modelo de focalização da política social, que envolve responsabilidades partilhadas entre Estado e sociedade, no encaminhamento da assistência aos mais pobres. A ideia é fortalecer a capacidade dos pobres de lutar contra pobreza, integrados à dinâmica do mercado, potencializando, ao mesmo tempo, o consumo interno. Essa mudança obedece a alguns princípios: o estratégico (flexibilidade e segmentação da focalização); o societário, de caráter local (partilha de responsabilidades entre público e privado via sistemas de governança local); o da racionalidade econômica do mercado (mediante a transferência direta de renda aos beneficiários dos programas, que se transformam em consumidores).

O centro da política social, no contexto atual, desloca a dimensão mais universalista de direitos e redistribuição da riqueza nacional para o tratamento compensatório da assistência a partir dos seus efeitos - a pobreza, a miséria -, aprofundando o conflito redistributivo na base da pirâmide da ren-

${ }^{31}$ O campo de atuação das políticas sociais, no Brasil, após a Constituição de 1988, estrutura-se em torno de três núcleos de direitos (IPEA, 2003): (i) aquele dos direitos sociais básicos estruturados no aparelho do Estado; (ii) os vinculados constitucionalmente, que respondem pela garantia dos direitos sociais básicos constitucionais, mas não estão protegidos de cortes orçamentários (Ex. Programa de Reforma Agrária; Fome Zero); e (iii) e os programas emergenciais dirigidos a atenuar situações de vulnerabilidade social de segmentos específicos (Ivo, 2004a).

${ }^{32}$ Esse Estado foi apenas parcialmente implantado no Brasil. Os direitos sociais restringiam-se à camada de trabalhadores assalariados do mercado de trabalho formal. A Constituição de 88 universalizou o direito à assistência como política securitária de proteção a todos os cidadãos. 
da, entre "pobres" e "quase pobres", ou seja, pessoas em condição de pobreza e trabalhadores assalariados. Como indica Lautier (1999), "desvinculando a pobreza dos seus determinantes estruturais, separam-se os indivíduos submetidos a essa condição dos seus lugares no sistema produtivo".

Assim, o encaminhamento da integração social com base na erradicação da pobreza desvincula os "pobres" do sistema de proteção social, e da estruturação do mercado de trabalho, passando a assistência a constituir-se como um atributo individual "moral" dos "mais" necessitados. Essa reconversão transforma o princípio da universalidade dos direitos sociais em programas e medidas técnicas e estratégicas de selecionar, controlar e atribuir benefícios a grupos de famílias, não se constituindo em direitos (Ivo, 2001, 2004a), ainda que operem o alívio das condições de extrema pobreza.

A responsabilidade do Estado no provimento do bem-estar é reorientada para a norma da eficiência na seletividade e acompanhamento das condicionalidades. Institui-se, assim, um novo paradigma da "justiça social com eficácia" (Ivo, 2011), pelo gerenciamento da distribuição dos mínimos sociais para os que realmente precisam, evitando-se, de acordo com essa tese, supostos desvios nos gastos sociais. No caso do Brasil, o Programa Bolsa Família manteve, nos últimos anos, um patamar de $0,4 \%$ do PIB, e a expansão e o crescimento do programa foi possível pelo crescimento da renda nacional. ${ }^{33}$ Para os desamparados da proteção pública, desenvolvem-se também políticas de proteção civil (Castel, 2004) da "ordem", voltadas para conter as máfias e o crescimento da violência, especialmente nas periferias urbanas. Substitui-se, portanto, a política do welfare por políticas coercitivas de proteção civil na constituição de um aparato de segurança pública para os setores populares.

A aplicação massiva desses programas de transferência de renda, a valorização do salário

${ }^{33} \mathrm{O}$ programa Bolsa Família se expandiu rapidamente e hoje atinge 12,8 milhões de famílias com um gasto de 14,8 bilhõ̃es, o que representa $0,4 \%$ do PIB desde 2009 . Entre 2003 e 2010, ele incorporou 9 milhões de famílias, passando de 3,6 milhões de famílias beneficiadas em 2003 para 12,8 milhões, em 2010 . mínimo e a recuperação de postos de trabalho protegidos, juntos, influenciaram a queda dos indicadores de desigualdades de renda. Isso teve impacto político e simbólico, especialmente no ambiente internacional, consolidando a "prova da eficácia" do modelo de transferência de renda em favor do mercado, o que estaria favorecendo a mobilidade social e a expansão de uma nova classe média, festejada pelos agentes do mercado.

Do ponto de vista analítico, no entanto, é importante considerar o illusio que reafirma o mercado como instância justa e autorregulável. Em primeiro lugar, a renda, apesar de relevante, não é suficiente para determinar mudança de classe social. Nos setores populares, ela é extremamente variável, em função da incerteza e da vulnerabilidade do trabalho informal. A incorporação de capital cultural constitui-se também, segundo Bourdieu, em fundamento da hierarquia social, definindo as condições distintas de apropriação de bens materiais e ideais, como analisa Souza (2010). Do ponto de vista da relação de trabalho, a renda não explicita a precarização das relações de trabalho, os déficits de educação e o capital cultural, valorizando mais o aumento do consumo. O triunfalismo do "consumo dos pobres" reproduz outra illusio, a que considera que a nova "classe média" formaria agora a espinha dorsal da estrutura social brasileira.

\section{CONCLUSÃO}

Este trabalho buscou historicizar os contextos que alteram a natureza dos atores, do Estado e das políticas, com ênfase nos vetores do conflito nas relações internas e externas, e o das desigualdades e da integração, da perspectiva da regulação das políticas sociais do Estado em vista dos objetivos de bem-estar e de cidadania. As alternativas de encaminhamento da integração social, no período pós-consenso de Washington, nos anos 2000, mostram como as políticas sociais, ajustadas ao mercado e orientadas segundo princípios de gestão estratégica da focalização do Estado "eficiente”, apresentam limites no padrão da distribuição, 
nos direitos da cidadania e nos objetivos mais amplos da seguridade econômica e alimentar, sem desconhecer as melhorias no alívio das famílias em condição de pobreza. ${ }^{34}$

Diante da intervenção do Estado em políticas massivas dirigidas aos segmentos mais pobres - o que resultou num padrão de crescimento com redistribuição, em países da América Latina-, alguns autores e agências (CEPAL, 2010; Delacourt, 2009) indagam se estamos voltando a políticas keynesianas centradas num papel central e intervencionista do Estado como indutor de um desenvolvimento sustentado na consolidação do mercado interno. Nesse caso, as políticas massivas de transferência de renda teriam fomentado a economia popular na constituição de um processo de desenvolvimento endógeno.

Bresser Pereira $^{35}$ (2006) e Renato Boschi e Flávio Gaitán (2008), ${ }^{36}$ como outros economistas, reabrem o debate sobre um neodesenvolvimentismo no Brasil, que articula instituições de governo e instituições econômicas na coordenação de um acordo nacional para crescimento e distribuição. Boschi e Gaitán (2008) advertem que esse acordo “[...] não significa subsumir a política ao domínio da economia, senão [...] reclamar a necessidade de cada sociedade de estabelecer acordos mínimos que permitam o desenvolvimento e o bem-estar" (p.313). Nesse sentido, eles reconhecem que a agenda so-

${ }^{44}$ Sobre a perspectiva das políticas sociais e do padrão das desigualdades como elementos de sustentabilidade para o Brasil na crise, ver Ivo e Laniado (2012).

35 Bresser Pereira (2006) defende um "novo desenvolvimentismo" para países de desenvolvimento médio, como o Brasil, que deve expressar um novo acordo entre as classes sociais e um Estado forte, voltado para a construção de uma estratégia nacional de desenvolvimento (p.10-11), que contemple a manutenção da estabilidade macroeconômica, o fortalecimento do mercado e do Estado, com ênfase numa política industrial, e a promoção de poupança interna e inovação[p.19].

${ }^{36}$ Boschi (2008) considera que as mudanças operadas no capitalismo, em âmbito global, impedem retorno a modelos desenvolvimentistas clássicos. Para ele o "neodesenvolvimentismo" constitui "um modelo em formação, que postula a construção de um espaço de coordenação entre as esferas públicas e privadas, com o objetivo de aumentar a renda nacional e os parâmetros de bem estar social.” (p.306). ar a relevância da agenda social do desenvolvimento hoje implica analisar um padrão decisivo do Estado na distribuição e no enfrentamento da dimensão estruturante e qualificada de inserção pelo mercado de trabalho e na proteção sustentada em direitos sociais, ou na regulação das relações não mercantis (base de que tratam as políticas sociais). Conquanto se reconheçam resultados positivos no alívio à pobreza, políticas vigorosas de proteção e integração social não se restringem a programas governamentais de transferência de renda, mas dependem das condições estruturais da distribuição, da qualidade das políticas públicas e da qualidade de inserção dos indivíduos na esfera do trabalho, eixo fundamental da integração social. Os dispositivos normativos das agências multilaterais e dos agentes dos governos, relativos à tese da "eficiência do gasto social", geraram uma "comunidade epistêmica" (para usar expressão de Palier; Prévost, 2006), que reforça a eficácia da "focalização" na sustentação de um desenvolvimento "moralmente" mais justo, uma vez que orientado para os que mais precisam. A aplicação massiva das políticas de transferência de renda e seus efeitos sobre o mercado interno e sobre indicadores de desigualdades, ainda que tenham resultado também e, sobretudo, da ação de outras políticas (como a aplicação de direitos básicos constitucionais, a aposentadoria rural e o aumento do salário mínimo), consolidam um convencimento generalizado sobre um novo Estado social "eficiente" pró-pobres, considerado, dessa perspectiva, como socialmente mais justo, porque redistribui renda a aqueles que "efetivamente" dela mais precisam. Alguns sociólogos (Dowbor, 2008) destacam a potencialidade dos programas de transferência de renda e do microcrédito como dinamizadores de um "círculo virtuoso" da microeconomia e da inserção social, estímulo ao mercado interno, o que pode impactar positivamente sobre a mobilidade social mais ampla. Outros (Asseburg; Gaiger, 2007) reconhecem esses valores, mas advertem sobre os seus alcances limitados em relação às condições estruturais da distribuição, à qualidade das políticas públicas e à natureza precarizada das relações de trabalho. 
Essas mudanças exigem retorno a um debate sociológico sobre um novo modelo de desenvolvimento em formação e sobre as perspectivas mais universalistas das políticas sociais, que indague a "quem" se dirigem os resultados dessas políticas, o "como" se está crescendo e "quem paga” os custos desse modelo. A resposta a essas questões exige uma agenda de pesquisas sobre as mudanças em curso e sobre os limites do crescimento endógeno, determinante para os objetivos de sustentabilidade do desenvolvimento, considerando-se a disjunção entre capital e trabalho, diante da crise estrutural e histórica contemporânea.

(Recebido para publicação em 12 de março de 2012) (Aceito em de 18 de junho de 2012)

\section{REFERÊNCIAS}

ACHARD, Diego; FLORES, Manuel. (Org.) Governabilidad: un reportage de América Latina. México: Fondo de Cultura Económica, 1997.

ABREU, Alzira A. O ISEB e o desenvolvimentismo. Rio de Janeiro: FGV. Disponível em: http://cpdoc.fgv.br/producao/ dossies/JK/artigos/Economia/ISEB. Acesso em: 10 abr. 2012.

ARRUDA, Maria Arminda do Nascimento. Florestan Fernandes, vocação científica e compromissos de vida. In: BOTELHO, André; SCHWARCZ, Lília M. (Org.) Um enigma chamado Brasil: 29 intérpretes e um país. São Paulo: Companhia das Letras, 2009. 310-323p.

ASSEBURG, Hans B.; GAIGER, Luiz Inácio. A economia solidária diante das desigualdades. Dados: revista de ciências sociais, Rio de Janeiro, v. 50, n.3, p.499-533, 2007.

AZEVEDO, Thales de. Les élites de couleur dans une ville brésilienne. Paris: Unesco [1953].

BAAS, S. Participatory institutional development. In: CONFERENCE ON SUSTAINABLE AGRICULTURE AND SAND CONTROL IN GANSU DESERT AREA, Pequim, 38 nov. 1997.

BARBA C.; IVO, Anete B. L.; VALENCIA, E.; ZICCARDI, A Research horizons: poverty in Latin America. In: OYEN, E. The polyscopie landscape of poverty research. State of art in international poverty research. Bergen: CROP/ISSC International Social Science Council/ Norway: Research Council of Norwary, apr., 2005. 182p. webside: www.crop.org

BOSCHI, Renato. Descentralização, clientelismo e capital social na governanca urbana: comparando Belo Horizonte e Salvador. Dados: revista de ciências sociais. Rio de Janeiro, IUPERJ, v.42 , n.4, p.655-690, 1999

; GAITÁN, Flávio. Intervencionismo estatal e políticas de desenvolvimento na América Latina. Caderno $C R H$ : revista do Centro de Recursos Humanos da UFBA, Salvador, v.13, n.53, p.305-322, maio/ago. 2008.

BOTELHO, André; SCHWARCZ, Lília M. (Org.) Um enigma chamado Brasil: 29 intérpretes e um país. São Paulo: Companhia das Letras, 2009.
BRESSER PEREIRA, Luis Carlos. O conceito de desenvolvimento do ISEB rediscutido. Dados: revista de ciências sociais, Rio de Janeiro, IUPERJ, v.47, n.1, p.49-84, 2004.

O novo desenvolvimentismo e a ortodoxia convencional. São Paulo em Perspectiva, São Paulo, v. 20 n.3, p. 5-24, jul./set. 2006.

BULLEN, P; ONIX, J. Measuring social capital in five communities in NSW, Center for Australian Community Organizations and Management. Working Paper Series, n.41. Sidney: University of Technology, 1998 (Cit. Kliksberg, 2000).

CASTEL, Robert. La inseguridad social: que es estar protegido? Buenos Aires: Manacial, 2004.

CHAUÍ, Marilena. Brasil: mito fundador e sociedade autoritária. São Paulo: Fundação Perseu Abramo, 2000.

CARDOSO, F. H. Comentario sobre los conceptos de sobrepoblación relativa y marginalidad. Revista Latinoamericana de Ciencias Sociales, Santiago do Chile, ELAS/ICIS, n.1/2, p.57-76, 1969.

FALETTO, Enzo. Dependência e desenvolvimento na América Latina. Rio de Janeiro: Zahar Editores, 1970.

La sociedad cerco al Estado. Entrevista. In: ACHARD, Diego; FLORES, Manuel. (Org.) Governabilidad: un reportage de América Latina. México: Fondo de Cultura Económica, 1997. p.80-90.

CARVALHO, José Murilo de. Entrevista. In: CORDEIRO, L.; COUTO, J. G. (Org.) Quatro autores em busca do Brasil: entrevistas a José Geraldo Couto. Rio de Janeiro: Rocco, 2000. p.9-29.

CEPAL. Comissão Econômica para América Latina e o Caribe Panorama Social da América Latina 2010. 2011. Disponível em: www.eclac.org/publicaciones/xml/6/41806/ PSP-panoramasocial2010.pdf. Acesso em: 23 maio 2011.

CPDOC/FGV. Jucelino Kubischeck . Disponível em: http:/ /cpdoc.fgv.br. Acesso em:10 abr. 2012.

COLEMAN, J. Foundations of social theory. Cambridge, MA: Harvard University Press, 1990.

CROZIER, Michel; HUNTINGTON, Samuel; WATANUKI, Joji. The crises of democracy. Report on the governability of democracies to the trilateral commission. New York: New York University Press, oct., 1975.

DOWBOR, Ladislau. Em defesa dos "territórios da cidadania”. Le Monde Diplomatique, Brasil, 18.mar. 2008. Disponivel em: http://diplo.dreamhosters.com/200803,a2265.html

DELCOURT, Laurent. Rétour de l'état. Pour quelles politiques sociales? [Editorial]. Alternatives Sud, Paris, Louvain-la Neuve, v.16, p.7-36, 2009. (Editions Syllepse)

DINIZ, Eli. Crise, reforma do Estado e governabilidade: Brasil, 1985-95. Rio de Janeiro: Fundação Getúlio Vargas, 1997.

ESPING-ANDERSEN, Gosta. The three worlds of welfare capitalism. Cambridge: University Press, 1990.

FAORO, Raymundo. A questão social: a modernização. Estudos Avançados, São Paulo, v.06, n.14, jan./abr. p.722, 1992

FIEDMANN, John. Empowerment: uma política de desenvolvimento alternativo. Lisboa: Celta Editora, 1992.

FRAZER, Nancy. Justice interruptus: critical reflections on the 'Post-socialist'condition. New York: Roudtledge, 1997. FREIRE, Gilberto. Casa Grande \& Senzala. Rio de Janeiro: Global, [1933] 2006.

FERNANDES, Florestan. Mudança social no Brasil. São Paulo: Difel, 1960. 
GÉGUEN, Haud; MALOCHET, Guillaume. Les théories de la reconnaissance. Paris: La Découverte, 2012.

GOHN, Maria da Glória. A força da periferia: a luta das mulheres por creches em Sã̃o Paulo. Petrópolis: Vozes, 1985.

Abordagens teóricas no estudo dos movimentos sociais na América Latina. Caderno CRH: revista Centro de Recursos Humanos da UFBA, Salvador, v.21, n. 54 p.438-455, set.dez., 2008.

HOLANDA, Sérgio Buarque de. Raízes do Brasil. São Paulo: Companhia das Letras, [1936] 1996.

HONNETH, Axel. La lutte pour la reconnaissance. Paris: Le Cerf, [1992] 2002.

IVO, Anete B. L. Metamorfoses da questão democrática: governabilidade e pobreza. Buenos Aires: CLACSO/ASDI, 2001

A reconversão do social: dilemas da redistribuição no tratamento focalizado. São Paulo em Perspectiva, São Paulo, SEADE, v.18, n.2, p.57-67,abr./ jun,2004a.

A urban governance e as políticas sociais: entre consentimento e emancipação In: ZICCARDI, A. (Org.) Partcipación ciudadana y políticas sociales en el ámbito local. México: UNAM/IIS/INDS/Consejo Mexicano de Ciencias Sociales, 2004b. p.77-104.

(Org.) Regimes de bem-estar na América Latina"[Introdução a Dossiê] Caderno CRH: revista do Centro de Recursos Humanos da UFBA, Salvador, EDUFBA, v.20, n.50, 2007.

Viver por um fio pobreza e políticas sociais São Paulo: Annablume; Salvador: CRH;UFBA, 2008.

Bolsa Família: caminhos da coesão social ou segmentação da pobreza?. In: BARBA, C.; COHEN, N. (Org.) Perspectivas críticas sobre la cohesión social. Buenos Aires: CLACSO, 2011. p.171-194.

IVO, Anete B.L.; LANIADO, Ruthy N. The Brasilian Approch to Crisis: Growth Recovery, Basic Social Income and a Wide Social Pact. In: SCHUERKENS, Ulrike (Ed.) Socio-economic outcomes of the global financial crisis. New York/Londres: Ed. Routledge, 2012. p.210-238.

IANNI, Otávio. Língua e sociedade .primeira versão. Campinas: Unicamp;IFCH, 1999.

JACOBI, P. Movimentos sociais e políticas públicas: demandas por saneamento e saúde. São Paulo: Cortez, 1989

JACOME, Iram; CUNHA,Carmem; RAMALHO, José R.;

SANTANA, Marco A. Velhos e novos operários da indústria automobilística: comparações entre o ABC paulista e o Sul Fluminense. Caderno CRH: revista do Centro de Recursos Humanos da UFBA, Salvador, v.19, n. 46, p.7585, jan./abr. 2006.

JOSEPH, J. Democracy's social capital: civil society in a new era. [S.l.], Adress. 1998.

LEBAUSPIN, Ivo. Por uma nova concepção de desenvol2010.

LEBORGNE, Danielle; LIPIETZ, Alan.Two social strategies in the production of new industrial spaces. In: BENKO, G.; DUNFORD, M. (Ed.) Industrial change and regiona development. London: Pinter Publisher-Belhaven Press, 1991a.

L’après-fordisme: idées fausses et questions ouvertes Espaces et Sociétés Paris n.66, 1991b. [Couverture orange CEPREMAP, 9103,1990]

Le GALÈS, Patrick. Du gouvernement des villes à la gouvernance urbaine. Revue Française de Science Politique, Paris, n.45, p.57-94, 1995.
LAUTIER, Bruno. Les malheureux sont les puissants de la terre.... (répresentations et régulations étatiques de la pauvrété en Amérique Latine). Revue Tiers Monde, Paris, PUF, v.36, n.142, p.383-409, avr./juin, 1995.

Les politiques sociales en Amérique Latine. Propositions de méthode pour analyser en éclatement en cours. Cahiers des Amériques Latines, Paris, IHEAL Editions, n.30, p.19-44, 1999.

MELO, Marcos André. 'Governance' e reforma do Estado: o paradigm agente X principal. Revista de Serviço Público, Brasília, v.120, n.1, p.67-82, jan.-abr. 1996.

MDS. Ministério de Desenvolvimento Social e Combate à Fome. Desenvolvimento Territorial. Disponível em www.mds.gov.br/segurancaalimentar/desenvolvimentoterritorial. Acesso em: 15. ago. 2012

MOSER, C. Confronting crises: a summary of household responses to poverty and vulnerability in four poor urban Communities. Washington D.C.: World Bank, 1996. (ESD studies and monographs series n.7)

NUN, J. Superpopulación relativa, ejército industrial de reserva y masa marginal. Revista Latinoamericana de Sociología, México, v.5, n.2, p.178-236, 1969.

. Marginalidad y exclusión social. Buenos Aires: Fondo de Cultura Económica, 2001

NUNES, E. A gramática política do Brasil. Clientelismo e insulamento burocrático. Rio de Janeiro: Zahar Editores/ Brasília: ENAP, 1997

NURKSE, R. Problems of capital formation in underdeveloped countries. Londres: Blakcwell, 1963

OLIVEIRA, F. A economia brasileira: crítica à razão dualista. 2.ed. São Paulo: CEBRAP, [1972] 1976. p.7-78.

OSMONT, A. La 'gouvernance': concept mou, politique ferme. Annales de la Recherche Urbaine, Paris, Plan Urbanisme Construction Architecture, n.80-81, p.19-26, 1998.

ONU. Organização das Nações Unidas. The future we want. Disponível em: www.uncsd2012.org/thefuturewewant.html. Acesso em: 25 jun. 2012

PALIER, J; PRÉVOST, B. Le développement social. Nouveau discours et idéologie de la Banque Mondiale. Coloque International (État et régulation sociale) Institut National d'Histoire de l'Art. set. 2006.

PERRIN, G. Reflections on fifty years on social security. International Labor Review, [S.l.], v.22, n.99, 1969.

PNUD. Programa das Nações Unidas para o Desenvolvimento. Relatório do desenvolvimento para a erradicação da pobreza. Lisboa: Trinova Editora, 1997.

PRÉTECEILLE, E. Inégalités urbaines, gouvernance, domination? Réflexions sur l'agglomération parisienne. In: BALME, R.; FAURE et MALIBEAU (Dir.) Les nouvelles politiques locales. Dynamiques de l'action publique. Paris: Presses de Sciences Po, 1999. p. 57-76.

PRIETO, Mayra P. Espina. Desarrollo, desigualdad y políticas sociales. Acercamientos desde uma perspectiva compleja. La Habana: Publicaciones Acuario, 2010.

PRADO JUNIOR, Caio. Evolução política do Brasil. São Paulo: Revista dos Tribunais, 1933.

Revolução brasileira. São Paulo: Brasiliense, 1966

PUTNAM, R. Comunidade e democracia. A experiência da Itália moderna. Rio de Janeiro: Fundação Getúlio Vargas, [1994] 1996.

RAMALHO, José Ricardo; SANTANA, Marco Aurélio (Org.) Além da fábrica: trabalhadores, sindicatos e a nova questão social. São Paulo: Boitempo, 2003. 
; Novas conjunturas industriais e participação local em estratégias de desenvolvimento. Dados: revista de ciências sociais, Rio de Janeiro, v. 48, n.3, p.147-178, 2005.

JACOME, Iram. Sindicato, crise econômica e estratégias regionais: novas dimensões da participação política no ABC Paulista. Caderno CRH: revista do Centro de Recursos Humanos da UFBA, v.23, p. 339-351, 2010.

RICÚPERO, Bernardo. Caio Prado e o lugar do Brasil no mundo. In: BOTELHO, André; SCHWARCZ, Lília M. (Org.) Um enigma chamado Brasil: 29 intérpretes e um país. São Paulo: Companhia das Letras, 2009. p. 224-239.

SACHS, Ignacy. Caminhos para o desenvolvimento sustentável. Rio de Janeiro: Garamond, 2002.

Desenvolvimento: includente, sustentável, sustentado. Rio de Janeiro: Garamond, 2004.

SEN, A. K. Desenvolvimento como liberdade. São Paulo: Cia. das Letras, 2000.

SHEREN-WARREN, Ilse. et al. Cidadania e multiculturalismo: a teoria social no Brasil contemporâneo. Lisboa/Florianópolis: Socius/Edufsc, 2000.

A problemática da pobreza na construção de um movimento cidadão. Revista Política \& Sociedade, Florianópolis, Programa de Pós-Graduação em Sociologia Política, n.3, 2003.

SOUZA, Jessé de. A construção social da subcidadania: para uma sociologia política da modernidade periférica. Belo Horizonte: Editora UFMG, 2003.
Uma nova classe social. Entrevista concedida a Silvio Caccia Bava. Le Monde Diplomatique, v.4, n.40, nov. 2010. Disponivel em: http://diplomatique.uol.com.br/artigo. php?id=804. Acesso em: 13 jun. 2011.

VALLADARES, Lícia; COELHO, Magda. (Org.) Governabilidade e pobreza no Brasil. Rio de Janeiro: Civilização Brasileira, 1995.

VEIGA, José Eli. Desenvolvimento sustentável: o desafio do século XXI. Rio de Janeiro: Garamond, 2005.

VILLAS BOAS, Gláucia Mudança provocada: passado e futuro no pensamento sociológico brasileiro. Rio de Janeiro: Ed. FGV, 2006

WANDERLEY, Maria de Nazareth. A emergência de uma nova ruralidade nas sociedades modernas avançadas - 0 "rural" como espaço singular e ator coletivo. Estudos Sociedade e Agricultura, Rio de Janeiro, n.15, out. p. 87145,2000

WEGNE, Robert. Caminhos de Sérgio Buarque de Holanda. In: BOTELHO, André; SCHWARCZ, Lília M. (Org.) Um enigma chamado Brasil: 29 intérpretes e um país. São Paulo: Companhia das Letras, 2009. p.210-225.

WORLD BANK. Gouvernance and development. Washington DC: Ed. World Bank, 1992.

World development report 2000/2001: attacking poverty. Washington, DC. New York: Oxford University Press, 2001. 
THE PARADIGM OF DEVELOPMENT: from the founding myth to the new development

\section{Anete B.L. Ivo}

This paper aims at historicizing the contexts that reorient the concept of development in Brazil, from the 30s to the 80s, going through the neoliberal adjustment of the $90 \mathrm{~s}$, to the current inflections that question if the new massive and strategic interventionism of the State in social policies for the poorest points to a new model of development. The analysis presents inflections of the cepalino model, Cepal's theory (Economic Commission for Latin America) of the 50 s and 60s, in order to prioritize the social dimensions to mediate contradictions amongst economics, politics and institutional affairs. The leading thread adopts two analytical vectors: the topic of conflict (redistribution) and integration. The former is established on class coalitions and confrontation between national actors and multilateral agencies; integration, in the counterface of the conflict, takes into consideration the opening of public policies as well as the innovation of social and political actors in new arrangements oriented to the objectives of the social welfare and citizenship, from a more supported perspective.

KEY WORDS: development, modernization, structural adjustment, State, social policies, poverty.

\section{LE PARADIGME DU DÉVELOPPEMENT: du mythe fondateur au nouveau développement}

\author{
Anete B.L. Ivo
}

Cet article cherche à historiciser les contextes qui réorientent la notion de développement au Brésil, des années 30 aux années 80, en passant par l'ajustement néolibéral des années 90 pour en arriver aux inflexions actuelles qui se demandent si l'interventionisme massif et stratégique de l'État au sein des politiques sociales en faveur des plus pauvres est le signe d'un nouveau modèle de développement. L'analyse montre des inflexions du modèle cépalien des années 50-60 et essaie de donner la priorité à des dimensions sociales dans la médiation des contradictions entre l'économie, la politique et l'institutionnel. Le fil conducteur suit deux vecteurs d'analyse: le thème du conflit (redistributif) et celui de l'intégration. Le premier se base sur les coalitions de classes et les conflits entre les acteurs nationaux et les agences multilatérales; et celui de l'intégration, à l'opposé du conflit, qui considère l'ouverture des politiques publiques, mais aussi l'innovation acteurs sociaux et politiques dans de nouveaux arrangements qui visent des objectifs de bien-être social et de citoyenneté de manière plus soutenue.

Mots-CLÉs: développement, modernisation, ajustement structurel, État, politiques sociales, pauvreté.

Anete B.L. Ivo - Socióloga. Doutora em Sociologia. Professora do Programa de Pós-Graduação em Ciências Sociais da UFBA. Pesquisadora do Centro de Recursos Humanos da UFBA. Titular da Cátedra Simon Bolivar (Université de Paris III, 2000). Professora visitante da Université Paris XII (2006). Pesquisadora visitante do CREDAL-CNRS (1991). Editora do Caderno CRH (1996 a março de 2012). Seus trabalhos tratam sobre modernidade, questão social, Estado, espaço público e local governance. Publicou, entre outros, Metamorfoses da Questão Democrática (Buenos Aires, 2001) e Viver por um fio [...] (Annablume, 2008). Em co-autoria com Ruthy Laniado, The Brasilian Approch to Crisis: [...] In: U. Schuerkens. Socio-economic Outcomes of the Global Financial Crisis (Routledge, 2012) e The Transformation of the Social Issue: [...]. In: U. Shuerkens. Globalization and Transformations of Social Inequality (Routledge, 2010). 